\title{
Paracoccidioidomycosis
}

\section{Intralesional therapy}

\author{
Manoel Jacobsen Teixeira ${ }^{3}$, Erich Talamoni Fonoff², \\ Luís dos Ramos Machado ${ }^{4}$, José Paulo Smith Nóbrega ${ }^{4}$, \\ Hugo Sterman-Neto ${ }^{1}$, Robson Luis Oliveira de Amorim ${ }^{5}$
}

Paracoccidioidomycosis (PCM) has been described in Europe, North, Central and South America ${ }^{1,2}$. Paracoccidioides brasiliensis is a saprophyte in soil and plants and reaches the host usually through the naso-oral route ${ }^{1,2}$. The pathological manifestations is associated with its clinical presentation ${ }^{1-3}$. Usually causes lesions in oral mucosa, lung, liver, spleen, lymph nodes, adrenal gland, bones and kidneys $^{4,5}$. Localized or diffuse lesions in the central nervous system (CNS) can occur in more than $10 \%$ of cases $^{6-8}$ and may present as meningoencephalitis, multiple granulomatous reactions, or isolated masses causing focal neurological signs, increased intracranial pressure and evidences of meningeal involvement ${ }^{1,2,4,5}$. The treatment of CNS PCM follows the general lines for the treatment of the lesion in other regions of the body ${ }^{2}$. Sulphonamides and amphotericin-B are the drugs of choice. Sulphonamides associated or not with pholates are prefered because they are easier to be administrated and causes low rate of side effects 9 . Amphothericin- $B$ is very toxic but is necessary when the infection becomes resistant to sulphonamides ${ }^{9}$. As the systemic administration does not provide enough concentration of amphothericin-B in the cerebralspinal fluid, the intrathecal injection may be necessary in some cases. Treatment with azole derivatives are also been used ${ }^{10}$. Itraconazole has been successfully used for CNS PCM and fluconazole could be an alternative for treatment because of its good penetration in CNS. Voriconazol is a new antifungal agent that could have a role in treatment of CNS PCM due its good penetration in CNS too ${ }^{11}$. When intracranial expanding lesions are present, surgical removal of the granulomas and the abscess may be necessary ${ }^{1,2}$.

We describe the treatment of a patient with Paracoccidioides brasiliensis thalamic brain abscess who did not improve with systemic treatment with sulphonamides and amphotericin-B but was cured with repeated stereotatic intralesional instillation of amphothericin-B.

\section{CASE}

A 32 year-old man was admitted with 2 months history of headache and progressive blurring of the vision in both eyes, weakness of right limbs and somnolence. His general physical examination was normal. However, he was disoriented and presented right grade III complete spastic hemiparesis, bilateral papilledema and right homonimous hemianopsia. The white blood cell count, the erythrocyte sedimentation rate and the chest and skull X-rays were normal. The CT-scan of the brain revealed a cystic mass with a narrow wall in the left thalamus (Fig 1A). The CSF contained 3 leucocytes $/ \mathrm{mm}^{3}, 30 \mathrm{mg} \% /$ $\mathrm{dL}$ of total protein, $50 \mathrm{mg} / \mathrm{dL} \%$ of glucose with bacterioscopic, mycologic, examination and cultures negative.

Under local anesthesia, the TeixeiraMicromar stereotactic frame (Micromar, Diadema, SP, Brazil) was firmly fixed to the head of the patient allowing the stereotomographic delineation of the left thalam-
Correspondence
Hugo Sterman-Neto

Rua Zacarias de Gois 955 / 91

04610-002 São Paulo SP - Brasil

E-mail: pzfaust@hotmail.com

Received 4 April 2009

Received in final form 16 August 2009

Accepted 28 August 2009

\section{PARACOCCIDIOIDOMICOSE: TERAPIA INTRALESIONAL}

Department of Neurology, Division of Functional Neurosurgery of the Hospital das Clínicas of São Paulo University Medical School, São Paulo SP, Brazil: 'MD, Resident of Neurosurgery; ${ }^{2} \mathrm{MD}$, PhD, Neurosurgeon; ${ }^{3}$ Head of the Discipline of Neurosurgery; ${ }^{4} \mathrm{MD}, \mathrm{PhD}$, Neurologist; ${ }^{5} \mathrm{MD}$, Neurosurgeon. 
ic mass. Having the geographic center of the mass as the target point (Fig 1B), through a left frontal burr-hole 10 $\mathrm{ml}$ of yellowish material was collected from the lesion with a $1.2 \mathrm{~mm}$ cannula. Intra-operative smear preparation showed the presence of yeast of Paracoccidioidis brasiliensis (Fig 2). Culture of this material confirmed the diagnosis. The patient was then treated with a course of sulphonamide during 12 weeks. However, the clinical condition deteriorated and the volume of the lesion increased. Therefore the patient was treated with a course of IV amphotericin-B. Despite this treatment, the CT findings and the clinical conditions did not improved but continued to deteriorate. The patient became torporous and the right hemiparesis became more severe. A $2.5 \mathrm{~mm}$ sylastic catheter was then inserted into the abscess and a Rickam reservoir was fixed to the burr hole. Daily injections of 2 $\mathrm{mL}$ of amphotericin-B (diluted $50 \mathrm{mg}$ in $10 \mathrm{~mL}$ ) into the cyst were then performed during four weeks, resulting in neurological improvement of the patient and in disappearance of the abscess (Fig 1C). The patient was then treated with sulphonamides during 6 months. After this period, the treatment was discontinued and he presented complete recovery of this normal neurological status. The follow-up period lasted 10 years.

\section{DISCUSSION}

The CNS involvement in PCM is secondary to a primary focus and it is not necessarily accompanied by dissemination of the disease, and in some cases it is the preferential location ${ }^{6,7}$. CNS paracoccidioidomycosis is a very rare event and the most common presentation is the granulomatous form ${ }^{6,7}$. Association with meningitis can occur in $17 \%$ of cases ${ }^{6}$. The diagnosis of brain abscess must be suspected when patients with systemic blastomycosis infection suddenly present acute or progressive neurological deficit. The CT-scan or magnetic ressonance with intravenous contrast infusion usually reveal the lesion and its consequences. Differential diagnosis includes: neoplasms, other infections such as bacterial or parasitic abscess ${ }^{3,12}$. Stereotaxic biopsy should be considered to confirm the diagnosis, as occurred in the present case.

This is the first reported case of CNS paracoccidioidomycosis abscess treated with intralesional instilla- tion of amphotericin-B. The method was safe and simple and should be considered when there is no improvement with the traditional therapeutics measures (sulfonamides or antimycotic $)^{1,9,13-15}$. Further studies are needed to establish the ideal dose of amphotericin-B for intralesional use and the duration treatment. The goal of this case report was the introduction of a new and minimally invasive surgical intervention to treat patients with refractory disease.

In conclusion, intralesional repeated instillation of amphotericin-B must be considered whenever systemic treatment of intracerebral Paracoccidioides brasilienses abscess fail. Further investigation of this subject still is needed.

\section{REFERENCES}

1. Bennet JE. Miscellaneous mycoses and algal infections. In: Kasper DL, Braunwald E, Fauci AS (Eds). Harrison's principles of internal medicine. $16^{\text {th }}$ ed. New York: McGraw-Hill, 2005:1192.

2. Martinez R. Blastomicose sul-americana (paracoccidioidomicose). In: Veronesi R, Focaccia R (Eds).Tratado de infectologia. $2^{\text {nd }}$ Ed. São Paulo: Atheneu, 2004:1101-1131.

3. Araujo JC, Werneck L, Cravo MA. South American blastomycocis presenting as a posterior fossa tumor: case report. J Neurosurg 1978;49:425-428.

4. Campos EC, Cardematori MS. Blasmoticose encefálica. Neurobiolgia 1963;26: 83-102.

5. Fava Netto C. The immunology of South-American blastomycosis. Mycopathologia 1965;26:349-358.

6. Almeida SM. Central nervous system paracoccidioidomycosis: an overview. Braz J Infect Dis 2005;9:126-133.

7. Fagundes-Pereyra WJ, Carvalho GT, Miranda Góes A, Chagas Lima e Silva F, Sousa AA. Central nervous system paracoccidioidomycosis: analysis of 13 cases. Arq Neuropsiquiatr 2006;64:269-276.

8. Magalhães ACA, Bacheschi LA, Caramelli P. Paracoccidioidomicose do sistema nervoso central: estudo de 5 casos por ressonância nuclear magnética. Rev Hosp Clin Fac Med 1993;48:94-97.

9. Bakleh M, Aksamit AJ, Tleyjeh IM, Marshall WF. Successful treatment of cerebral blastomycosis with voriconazole. Clin Infect Dis 2005;40:69-71.

10. Villa LA, Tobon A, Restrepo A, et al. Central nervous system paracoccidioidomycosis: report of a case successfully treated with itraconazol. Rev Inst Med Trop São Paulo 2000;42:231-234.

11. Kappe R. Antifungal activity of the new azole UK-109 (voriconazole). Mycoses 1999;42(Suppl 2):S83-S86.

12. Argollo A, Reis VLL, Niemeyer P, Vuono E. Central nervous system involvement in South American blastomycocis. Trans R Soc Trop Med Hyg 1978;72:37-39.

13. Borgia SM, Fuller JD, Sarabia A, El-Helou P. Cerebral blastomycosis: a case series incorporating voriconazole in the treatment regimen. Med Mycol 2006; 44:659-664.

14. Canelas HM, Pinto L F, Bittencourt JMT, Araujo RP, Aghinah A. Blastomicose do sistema nervoso. Arq Neuropsiquiatr 1951;9:203-222.

15. Cook PP. Amphotericin B lipid complex for the treatment of recurrent blastomycosis of the brain in a patient previously treated with itraconazole. South Med J 2001;94:548-549. 